\title{
Mining of thin coal seams using surface-underground methods
}

\begin{abstract}
Shallow hard coal deposits in the form of seams can be mined using surface-underground methods. These methods are characterized by the exploitation of the deposit from the surface, while the mining process itself takes place underground. The large variability of the mining and geological conditions was the reason for the emergence of many mining methods and systems as well as machines, sometimes used only locally in various parts of the world. The article presents the surface-underground methods used around the world. Attention is paid to unusual and rarely used methods and machines, which are not utilized in Polandfor various reasons. The present article discusses mining machines used in the methods of Highwall, Auger, and Punch longwall mining along with their types and varieties.
\end{abstract}

Key words: thin coal seams, Highwall mining, Auger mining, Punch longwall mining

\section{INTRODUCTION}

The exploitation of mineral deposits starts with the most attractive ones in terms of profitability and technical requirements. In the case of hard coal deposited in the form of seams, thin and highly inclined seams are omittedas long as theyare not necessary, especially when there is a combination of both. Thus, in many countries, there is a growing interest in thin and highly inclined seams resulting from their abundance and the need to meet power needs.

Historically, it can be said that the wide range of methods and systems as well as the machines used in the mining of thin coal seams in world underground mining has been significantly limited overthe last century $[1,2]$ and has been reduced to several proven solutions [3-5]. Solutions such as cutters, longwall shearers with a complex and unusual trajectory of cutting tool movement, multi-headed shearers, machines with various positioning and shapes of cutting heads, cavity shearers, plow-scrapers, drills, or active plows areno longer usedin most cases. Currently, the most commonly used mining machines are two-headed and two-armed longwall shearers, static coal plows, and milling heading machines. Less frequently used machines include drilling,drilling-milling machines (Marietta, Ural-20, or Xcel Miners 4-Rotor miners), andcutters. Of course, it should be noted that innovative solutions are still being developed; however, they are either at the design or prototype stage or are niche solutions $[3,5]$.

Presently, several dozen systems for mining thin seams are known, including ones for highly inclined seams. This article discusses three very interesting methods of exploiting thin seams; namely, Continuous Highwall, Auger, and Punch longwall mining (which are not and have not been used in Poland and are relatively unknown because of their niche use and do not have Polish nomenclature) [6]. The term „Highwall mining" can also be found in the literature as a common system name for both Continuous Highwall and Auger mining. These are systems of surfaceunderground mining without removing the overburden. The term "surface-underground mining" is aimed at drawing attention to the fact that mining (i.e., underground mining) is performed, but with direct access to the seam from the surface. These systems are used only in seams thatare accessible from the surface; i.e., the so-called exposed seams or outcropping seams. 
Information on other systems such as longwall, cut and fill, or sublevel caving can be found in the literature $[4,7,8]$. Their mechanization is mostly based on well-known solutions of machines such as roadheaders, drill carriages, loaders, haulers, conveyors, or various solutions of powered supports.

\section{THEAUGER MINING METHOD}

The auger mining method uses drilling and is the oldest of the surface-underground methods discussed here. It consists of making large-diameter entries using the rotary method at specified intervals (Fig. 1). The spaces left between the entries are support pillars. The cutting head loads the spoil onto the flight, which transports it outside to a scraper or belt conveyor. The method is characterized by low use of the deposit (30-40\%); at the same time, it is cheap and enables a quick start and end of an operation.

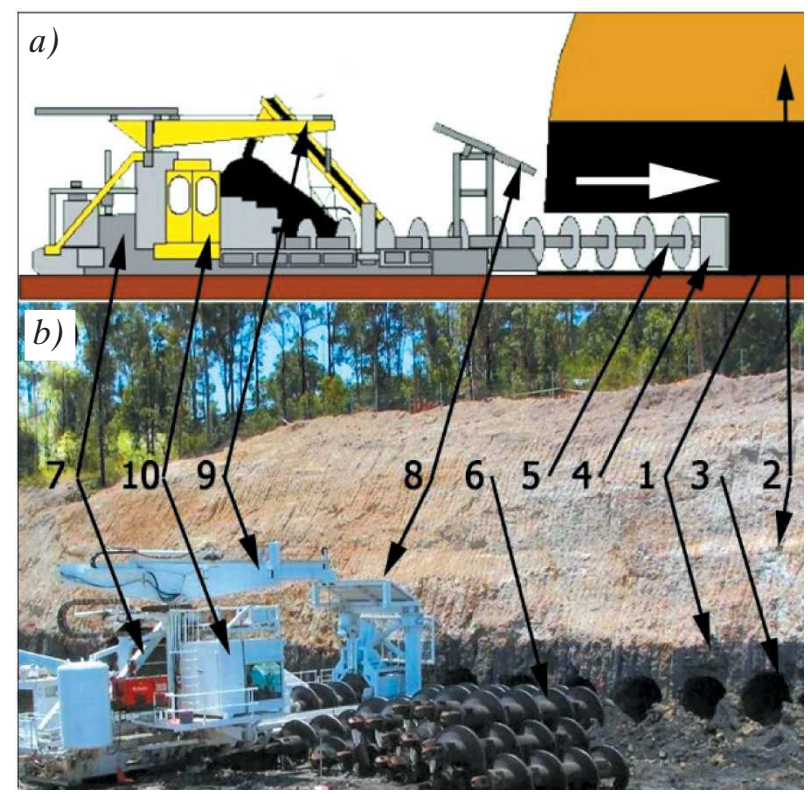

Fig. 1. Auger mining method: a) method scheme;

b) system in operation in Nicholas county, USA

1 - coal deposit, 2 - overburden, 3 - post-mininghole, 4 - cutting head, 5 - helical flange, 6 - shaft sections, 7 - drive, 8 - guard, 9 - crane, 10 - operator's cabin

The most advanced and largest mining machine used in this method is the Auger Miner 1500 (Fig. 2) from Coal Augering Service Pty Ltd. (CAS AM 1500). CAS is an Australian company offering coal mining services using the method of drilling and employs the technology of BryDet, the producer of the
BUA 600 machine for underground drill mining. The diameter range of the cutting heads ranges from $\phi 1200$ to $\phi 1900 \mathrm{~mm}$. The drilling depth reaches up to $203 \mathrm{~m}$ for an individual hole. At the worksite, the machine is set to the appropriate height by means of columns with a pitch of $2600 \mathrm{~mm}$ that (in addition to positioning) allowsfor the drilling of two horizontal holes (one above the other). After making the hole and withdrawing the shaft, the machine moves transversely with the aid of a rolling system made of two guides and a hydraulic mechanism. During assembly and disassembly (drilling, retraction), the flights are transferred with a crane [9].

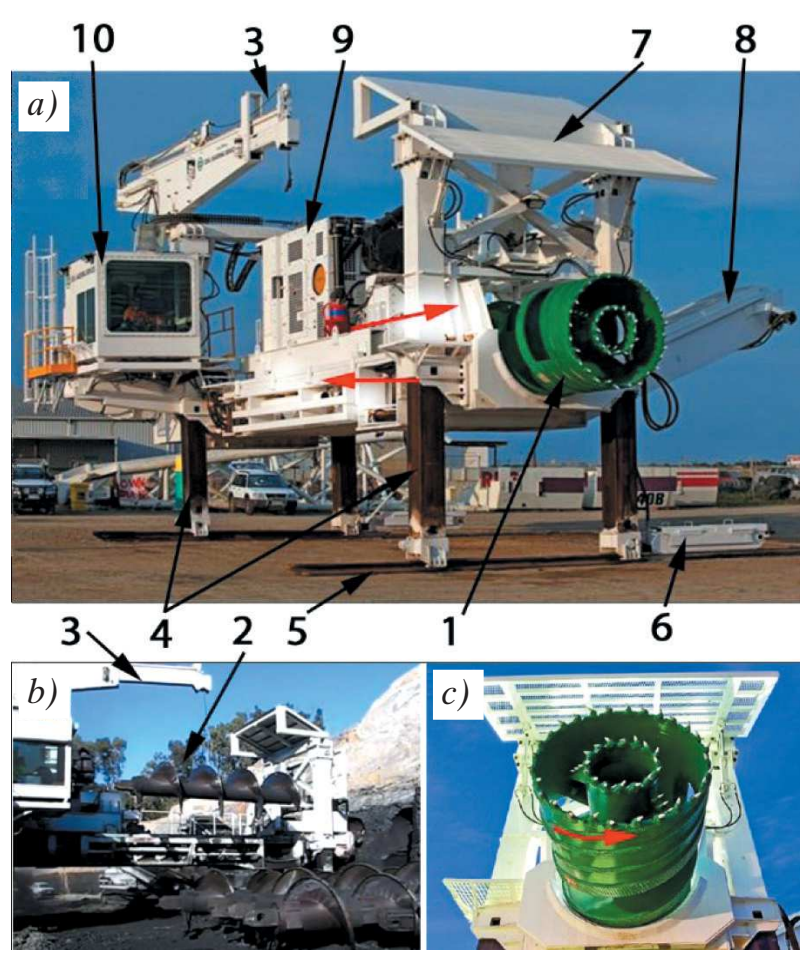

Fig. 2. Auger miner type mining machine: a) CAS AM1500 machine; b) shaft assembly; c) mining head 1 - cutting head; 2 - shaft sections, 3 - crane, 4 - columns, 5 - rolling system beam, 6 - rolling system actuators, 7-guard, 8-belt conveyor, 9-drive, 10-operator's cabin

Auger machines come in many versions that differ primarily in the diameter of the hole being made as well asthe number of heads. The diameter of the holes ranges from $\phi 400$ to $\phi 2500 \mathrm{~mm}$, and up to three holes can be made at the same time. An example of a machine with the smallest diameter and greatest number of simultaneously made holes is the MCK-GS MUL-T (Fig. 3) by Salem Tool Inc., which can mine a seam with three heads with a diameter of $\phi 400 \mathrm{~mm}$ at the same time. The length of the drilled hole reaches $150 \mathrm{~m}$ [10]. 


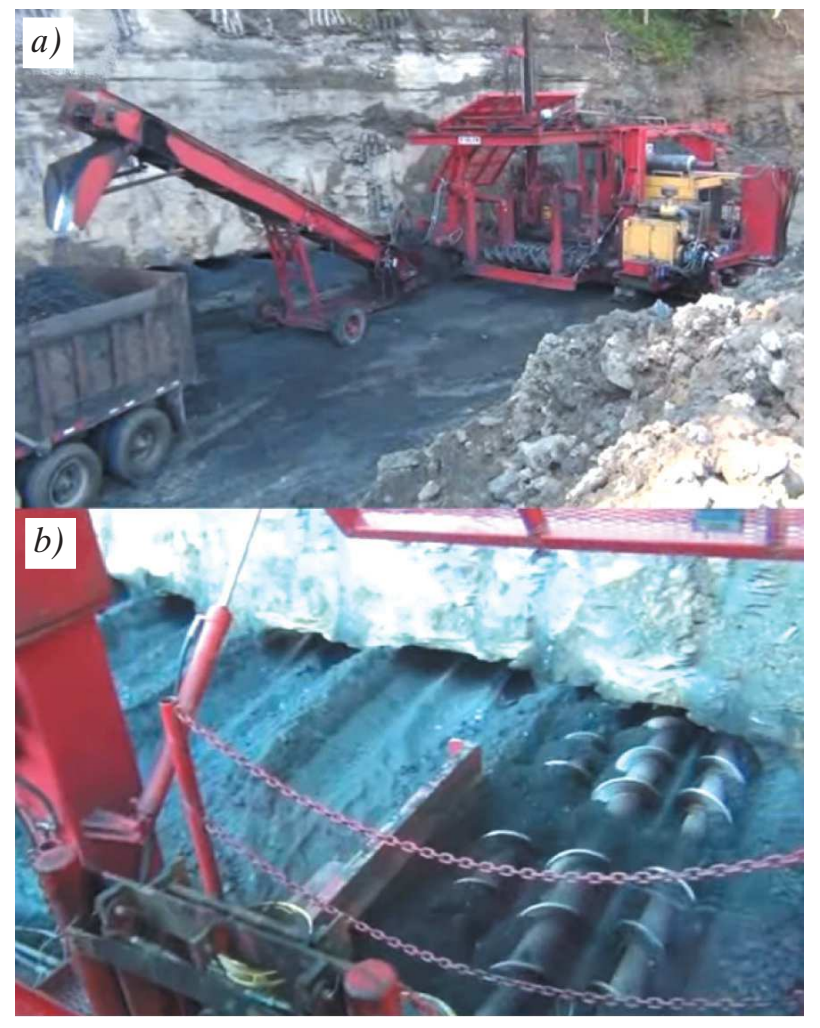

Fig. 3. Auger miner: a) MCK-GS MUL-T machine from Salem Tool Inc.; b) drilling with three heads

Machines used for drill mining allow for a very quick start of operation, and apart from providing media and maintenance, they only require an output transport system.

Auger mining technology in the underground version also utilizes the method of drilling, which is used for the exploitation of thin and residual seams. Mining consists ofthe selective excavation of the seam through large-diameter entries. Pillars are left between the individual entries to support the overburden. Both technology and machines can be found in articles where they are described using the examples of Ukrainian and Czech mining [11, 12].

The BryDet BUA 600 combine is also used for underground mining using the drilling method (Fig. 4). This machine is characterized by an interesting solution consisting ofthe use of two units: a mining unit and a withdrawing one. Both units work simultaneously, and during drilling and retraction, the shafts are transferred from one hole to the other, which allows us to minimize the shaft storage size and increase efficiency. Changing the distance of both units inrelation to one another simultaneously determines the width of the protective pillar. The BUA 600 machine can produce holes with diameters ranging from $\phi 1000$ to $\phi 1800 \mathrm{~mm}$ and up to $80 \mathrm{~m}$ in depth.
The drive power of the drilling unit is $450 \mathrm{~kW}$, and the withdrawing unit's power $-110 \mathrm{~kW}$. The total weight of the machine is $60 \mathrm{Mg}$ and requires a cast $6 \mathrm{~m}$ wide and $1.8 \mathrm{~m}$ high [13] for installation. Despite its typical underground application, the BUA 600 has been discussed due to its interesting and applicable technical solution in surface mining.
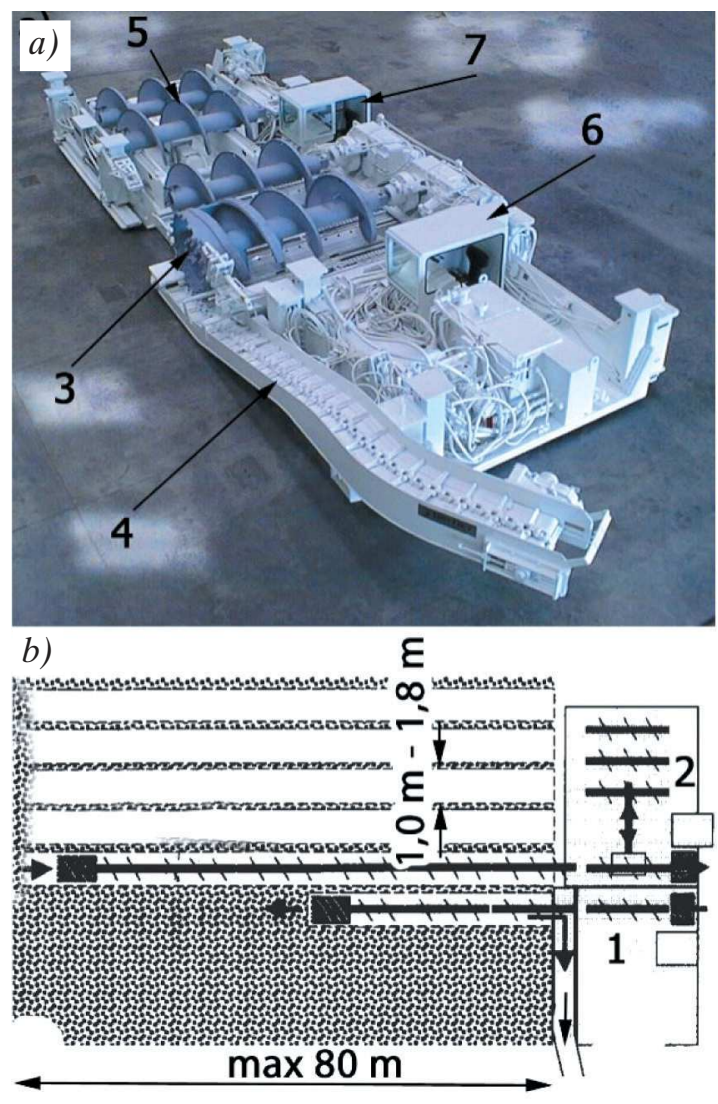

Fig. 4. Auger miner: a) BryDet's BUA 600 machine; b) operation technology

1 - drilling unit, 2 - withdrawing unit, 3 - cutting head, 4 - scraper conveyor, 5 - shaft sections, 6 - drilling unit operator's cabin, 7 - withdrawing unit operator's cabin

\section{CONTINUOUS HIGHWALL MINING METHOD}

The Continuous Highwall Mining method initially used a mining machine built on the basis of a continuous miner. In newer solutions designed specifically for thin seams, a separate mining machine is used. The method consists ofmaking subsequent galleries separated by protective pillars, which means that the use of the seam varies at around $60 \%$. The spoil is transported outside using double auger conveyors. In both methods (Auger and Highwall), mining takes 
place without human intervention at the face, which removes the necessity of using classic ventilation forthe excavations and securing the roofs (Fig. 5).
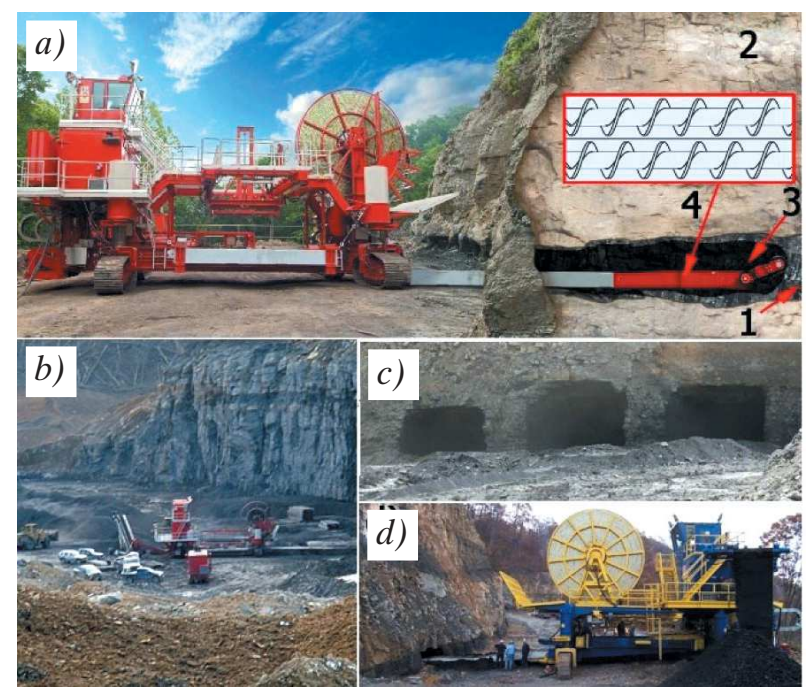

Fig. 5. Highwall mining method: a) method scheme; b) cast equipment along with the Terex SHM miner; c) casts after exploitation in Mingo county, USA; d) AHS American Highwall Systems type mining machine 1 - coal seam, 2 - overburden, 3 - cutting head,

$$
4 \text { - auger conveyor }
$$

A machine used in this technology is the CAT HW300, which is technically a Terex SHM miner (Fig. 6).

a)
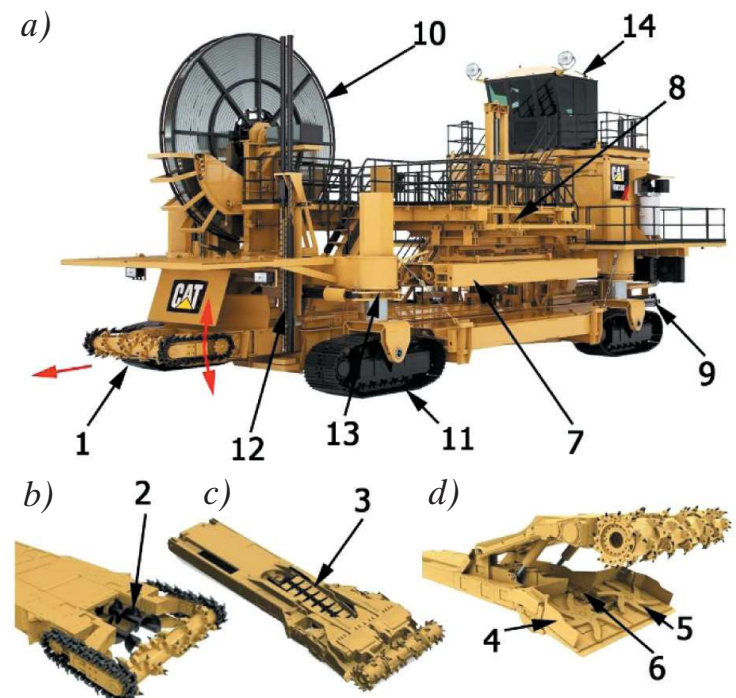

Fig. 6. HW300 CAT miner: a) miner, modules; b) XLPCM; c) LPCM; d) high

1 - cutting head, 2 - auger conveyor, 3 - scraper conveyor, 4 - loading spade, 5 - centrifugal loading arms, 6-scraper conveyor, 7 - pushbeam, 8 - gantry crane, 9 - feed system actuators, 10 - cable drum, 11 - caterpillar, 12 - an-

chor, 13 - column XII, 14 - operator's cabin
The HW300 miner is a powerful machine with a total power of $1600 \mathrm{~kW}$ and weighing $250 \mathrm{Mg}$ in the lightest configuration, which carries out the mining process to a depth of up to $300 \mathrm{~m}$. After having been set in the right position, the machineis stabilized with two anchors. The mining is carried out with acutting module pushed into the face by the feed system by means of hydraulic actuators with a pitch of $6.8 \mathrm{~m}$. Pushbeams with a length of $6 \mathrm{~m}$ are simultaneously the hull of the double auger conveyor and are transported during assembly and disassembly using a gantry crane. As with the front progresses, all cables are unwound from the cable drum [14].

The HW300 miner has four compatible cutter modules used depending on the thickness of the seam:

- XLPCM - ultra low module - cutterhead diameter $\phi 648 \mathrm{~mm}$, cutting height from 711 to $1549 \mathrm{~mm}$, cutting width $2946 \mathrm{~mm}$, weight $23.1 \mathrm{Mg}$,

- LPCM - low module - cutterhead diameter ф648 mm, cutting height from 762 to $1575 \mathrm{~mm}$, cutting width $2946 \mathrm{~mm}$, weight $23.1 \mathrm{Mg}$,

- Mid - medium module, partly outranging thin layers - cutterhead diameter $\phi 965 \mathrm{~mm}$, mining height from $1200 \mathrm{~mm}$ to $3060 \mathrm{~mm}$, cutting width $3505 \mathrm{~mm}$, weight $42.8 \mathrm{Mg}$. Equipped with an additional scraper conveyor.

- High - high module, completely outranging thin seams - cutterhead diameter $\phi 965 \mathrm{~mm}$, mining height from $2400 \mathrm{~mm}$ to $4494 \mathrm{~mm}$, cutting width $3505 \mathrm{~mm}$, weight $48.5 \mathrm{Mg}$. Equipped with a loading spade with centrifugal loading arms and an additional scraper conveyor.

The HW300 harvester moves on four caterpillar trolleys fixed to the columns that allow for changing the height of the cutter module in relation to the floor and turning the machine as well as driving transversely. The machine is more than $20 \mathrm{~m}$ long, almost $12 \mathrm{~m}$ wide, and almost $9 \mathrm{~m}$ high [14].

Highwall mining machines are also available in the AHS version from American Highwall Systems. AHS harvesters are suited for exploiting seams with a dip of up to $30^{\circ}$ and undulate deposits (Fig. 6d) [15].

An interesting variant of the Highwall mining system is the ADDCAR system from UGM ADDCAR Systems, LLC (Fig. 7). The ADDCAR system is used in the same way as the HW300 and is designed for exploiting seams within arange of $0.76 \mathrm{~m}$ to $8.54 \mathrm{~m}$ in height and approximately $3.5 \mathrm{~m}$ wide. As a mining machine, one of the CAT or Joy continuous miners is 
used. It is also possible to use a roadheader with point cutting. However, in each case, a special design of the combine is required, adapted to be compatible with the ADDCAR system.

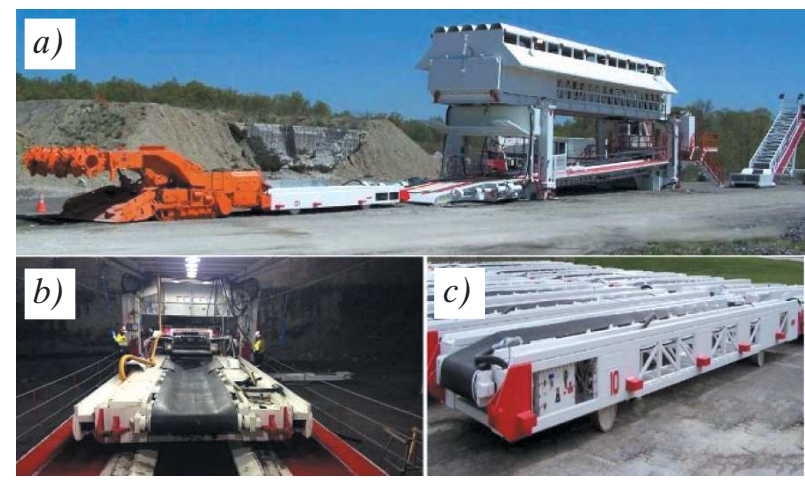

Fig. 7. ADDCAR system machines: a) complex;

b) transfer module assembly; c) transfer modules

The system is available in two varieties - Broad and Narrow Bench Highwall,with different maximum thicknesses of the seam and lengths of the gallery. The key feature of the ADDCAR system is the use of modules constituting independent cooperating belt conveyors. The 12.5-meter-long modules have a wheel chassis as well as their own drive and control systems. The modules thatare added during operation are connected mechanically and electrically. The system allows for the extraction of coal along a 488-meter-long gallery. An undeniable advantage of using belt conveyors is the significantly lower spoil degradation ascomparedtotransport by auger conveyors [16].

\section{PUNCH LONGWALL MINING METHOD}

The Punch longwall mining method (Fig. 8) consists ofthe extraction of seams, which are made available directly from the surface by making access excavations, using the longwall system. The excavations can be parallel or perpendicular to the direction of the longwall system's progress, in which case, the direction of exploitation is parallel to the excavations or is perpendicular to the boundary of the mining area towards the excavation. Protective pillars are left between consecutive fields. The wall equipment is an automated longwall system $[8,17]$. The use of automated longwall systems allows for the mining of seams of varying thickness and allows for obtaining a high (approximately 90\%) extraction of the deposit.

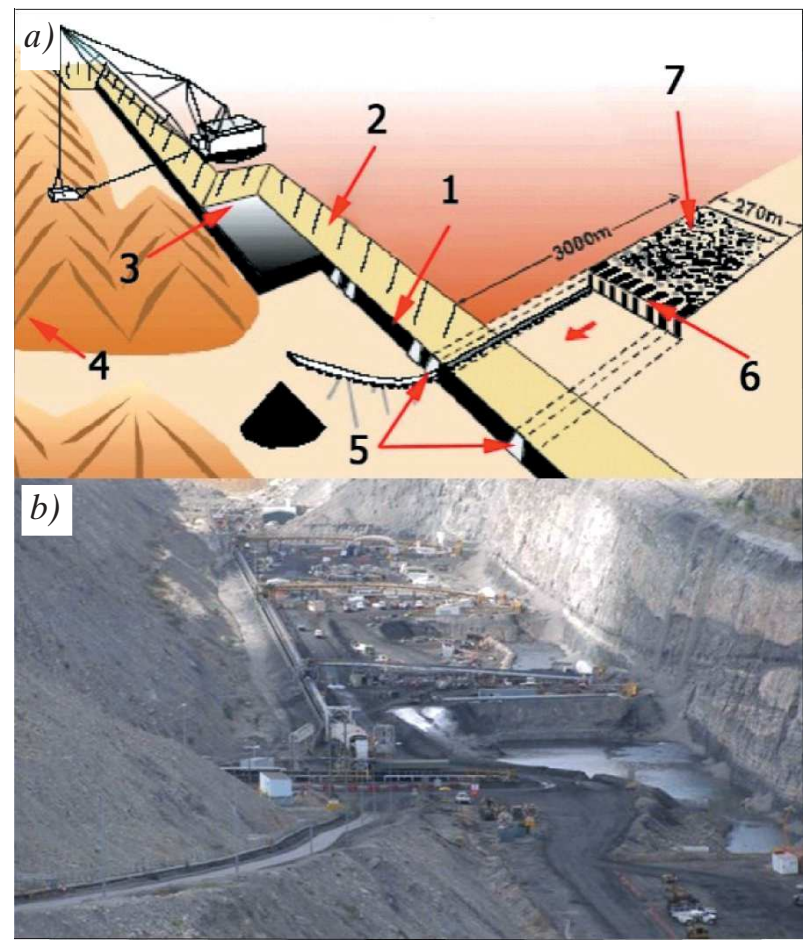

Fig. 8. Punch longwall mining: a) method scheme; b) Broadmeadow mine in Australia

1 - coal seam, 2 - overburden, 3 - excavation, 4 - spoil tip, 5 - longwall galleries, 6 - longwall system, 7 - goaf

In surface-underground methods, creeping scraper conveyors are also used. These are solutions involving remotely controlled machines that can traverse excavations thatare located in varying configurations with reference to one another, combining a mining machine with a subsequent means of hauling. Such solutions enable the use of various mining machines integrated with the conveyors.

\section{CONCLUSIONS}

The exploitation of thin and highly sloping seams, takes place using different methods and machines depending on many factors. Over the years, various mining machines have been used, although only a few proven solutions have remained. However, local conditions contributed to the development of mining methods and the machines they employ thatare utilized on a small scale in various parts of the world. The review of methods, systems, and mining machines presented in the article and the literature [5-8] indicates their great diversity. The machines presented in the article have been developed and used for many years. Despite the large variety of methods, 
the technique of mining is reduced to either milling or drilling. Depending on the method used and the possible need to protect the area above the excavations, the rate of deposit extraction varies from $30-40 \%$ for the Auger mining method, $60 \%$ for the Highwall mining method,andaround $90 \%$ for the longwall systems.

The article focuses on machines not used in Poland in the aspect of thin coal seams. The lack of their utilization in the country is due to the lack of favorable mining and geological conditions and the lack of exploitable shallow or exposed deposits.

All of the methods presented are also used for the mining of medium and thick seams. In those cases, the mining machine is characterized by a larger mining height. The only exception is the drilling method where the maximum diameter of the head is $\phi 2500 \mathrm{~mm}$ and the holes are made in two rows vertically.

\section{Acknowledgements}

Work financed from the Dean's Grant at the Faculty of Mechanical Engineering and Robotics at AGH University of Science and Technology as part of Agreement no. 15.11.130.838.

\section{References}

[1] Antoniak J., Opolski T.: Maszyny Górnicze, Maszyny do ek sploatacji podziemnej, Wydawnictwo "Śląsk," Katowice 1979.

[2] Opolski T.: Elementy urabiające nowoczesnych maszyn roboczych, Wydawnictwo "Ślask", Katowice 1966.

[3] Bołoz Ł.: Ocena obciażenia jednoorganowego kombajnu ścianowego na podstawie badań analitycznych, AGH w Krakowie, Kraków 2012 [praca doktorska].

[4] Piechota S.: Podstawowe zasady i technologie wybierania kopalin statych, Biblioteka Szkoły Eksploatacji Podziemnej, Kraków 2003.
[5] Kotwica K., Mendyka P., Bołoz Ł. et al.: Wybrane problemy urabiania, transportu i przeróbki skat trudnorabialnych. Czesśc I, pod red. Krauze K., Wydawnictwa AGH, Kraków 2016.

[6] Czaplicki J.: Mechanizacja w górnictwie okruchowym i skalnym. Kopalnie odkrywkowe złóż pokładowych $i$ rud metalicznych, Wydawnictwo Politechniki Śląskiej, Gliwice 2013.

[7] Bołoz Ł.: Maszyny urabiajace $w$ wybranych metodach eksploatacji cienkich pokładów węgla kamiennego, "Systemy Wspomagania w Inżynierii Produkcji, Górnictwo - Perspektywy i Zagrożenia: Węgiel, Tania Czysta Energia i Miejsca Pracy" 2018, 7, 1: 131-142.

[8] Bołoz Ł.: Maszyny urabiające $w$ ścianowych systemach eksploatacji cienkich pokładów węgla kamiennego, "Systemy Wspomagania w Inżynierii Produkcji, Górnictwo - Perspektywy i Zagrożenia: Węgiel, Tania Czysta Energia i Miejsca Pracy" 2018, 7, 1: 143-154.

[9] Coal Augering Services Pty Ltd, www.coalaugering.com [20.03.2018].

[10] Salem Tool Inc., www.salemtoolinc.com [20.03.2018].

[11] Rak Z., Skrzypkowski K., Stasica J.: Eksploatacja pokładów cienkich metodą zwiercania, "Przegląd Górniczy" 2014, 2, 18-24.

[12] Stonis M., Hudecek V.: Mining of Coal Pillars Using the Drilling Method, "Acta Montanistica Slovaca" 2009, 3, 241-249.

[13] BryDet, www.brydet.com [29.06.2018].

[14] Caterpillar Inc. (CAT), www.cat.com [29.06.2018].

[15] American Highwall Systems, American Highwall Mining Llc, http://americanhighwallsystems.com [29.06.2018].

[16] UGM ADDCAR Systems, LLC., https://addcarsystems.com [29.06.2018].

[17] Bołoz Ł.: Longwall shearers for exploiting thin coal seams as well as thin and highly inclined coal seams, "Mining - Informatics, Automation and Electrical Engineering" 2018, 2: 59-65.

ŁUKASZ BOŁOZ, Ph.D., Eng Department of Mining, Dressing and Transport Machines

Faculty of Mechanical Engineering and Robotics AGH University of Science and Technology al. Mickiewicza 30, 30-059 Kraków, Poland boloz@agh.edu.pl 


\title{
Urabianie cienkich pokładów węgla kamiennego metodami powierzchniowo-podziemnymi
}

\begin{abstract}
Złoża węla kamiennego zalegające płytko w postaci pokładów można eksploatować metodami powierzchniowo-podziemnymi. Sa to metody charakteryzujące się eksploatacja złoża z powierzchni, jednak sam proces urabiania odbywa się pod ziemiq. Duże zróżnicowanie warunków górniczo-geologicznych było przyczyna powstania wielu metod $i$ systemów eksploatacji oraz maszyn, stosowanych czasami jedynie lokalnie w różnych zakatkach świata. Przedstawiono stosowane na świecie metody powierzchniowo-podziemne. Zwrócono uwage na nietypowe i rzadko stosowane metody oraz maszyny, które z różnych względów nie występują w Polsce. Omówiono maszyny urabiające, pracujace w metodach highwall mining, auger mining, a także punch longwall mining wraz zich odmianami i typami.
\end{abstract}

Słowa kluczowe: cienkie poktady węgla kamiennego, highwall mining, auger mining, punch longwall mining

\section{WSTĘP}

Eksploatacja złóż zasobów mineralnych rozpoczyna się od najatrakcyjniejszych w aspekcie opłacalności oraz wymagań technicznych. W przypadku węgla kamiennego zalegającego w postaci pokładów, dopóki nie ma takiej konieczności, pomijane są pokłady cienkie i silnie nachylone, szczególnie gdy zachodzi kombinacja obu. Stąd w wielu krajach obserwuje się rosnące zainteresowanie pokładami cienkimi i silnie nachylonymi wynikające z ich dużej ilości przy jednoczesnej konieczności zaspokojenia potrzeb energetycznych.

Historycznie ujmując rozwój metod i systemów, jak również maszyn stosowanych przy eksploatacji cienkich pokładów węgla kamiennego można stwierdzić, że szeroki ich zakres w światowym górnictwie podziemnym w ubiegłym wieku $[1,2]$ został znacząco ograniczony i sprowadzony do kilku sprawdzonych rozwiązań [3-5]. Takie rozwiązania, jak: wrębiarki, kombajny ścianowe o złożonej i nietypowej trajektorii ruchu narzędzi skrawających, kombajny o wielu organach, maszyny o różnym usytuowaniu i kształcie głowic skrawających, agregaty wnękowe, strugozgarniarki, tarany czy strugi aktywne, w większości przypadków nie są już stosowane. Obecnie najpowszechniej użytkowanymi maszynami urabiającymi są kombajny ścianowe dwuramionowe i dwuorganowe, statyczne strugi węglowe oraz frezujące kombajny chodnikowe. Rzadziej wykorzystuje się maszyny takie jak kombajny wiercące lub wiercąco-frezujące (kombajny typu Marietta, kombajny Ural-20 lub XcelMiners 4-Rotor) czy wrębiarki. Oczywiście należy zaznaczyć, że nadal opracowywane są innowacyjne rozwiązania, jednak są one albo na etapie projektu, prototypu albo są rozwiązaniami niszowymi $[3,5]$.

Obecnie znanych jest kilkadziesiąt systemów eksploatacji pokładów cienkich, $\mathrm{z}$ uwzględnieniem pokładów silnie nachylonych. W artykule omówiono trzy interesujące metody eksploatacji pokładów cienkich, mianowicie continuous highwall mining, auger mining, oraz punch longwall mining, które nie są i nigdy nie były stosowane w Polsce, a ze względu na ich niszowe wykorzystanie są mało znane i nie mają polskiego nazewnictwa [6]. W literaturze spotkać można również określenie highwall mining jako wspólną nazwę systemu zarówno dla continuous higwall mining, jak i auger mining. Są to systemy eksploatacji powierzchniowo-podziemnej bez zdejmowania nakładu. Określenie powierzchniowo-podziemna eksploatacja ma na celu zwrócenie uwagi na fakt prowadzenia wydobycia, czyli urabiania pod ziemią, jednak $\mathrm{z}$ bezpośrednim dostępem do pokładu z powierzchni. Systemy te stosowane są tylko tam, gdzie jest dostęp do pokładu z powierzchni, czyli pokłady na niewielkich głębokościach lub pokłady odsłonięte, tak zwane exposed seams albo outcropping seams. 
Informacje o pozostałych systemach, takich jak ścianowe, ubierkowo-zabierkowe (cut and fill) czy podbierkowe (sublevel caving) można znaleźćw literaturze [4, 7, 8]. Ich mechanizacja opiera się najczęściej na znanych rozwiązaniach maszyn, takich jak kombajny chodnikowe, wozy wiertnicze, ładowarki, wozidła odstawcze, przenośniki czy różne rozwiązania obudów zmechanizowanych.

\section{METODA AUGER MINING}

Metoda auger mining wykorzystuje zwiercanie i jest najstarszą z omawianych metod powierzchniowo-podziemnych. Polega na wykonywaniu otworów wielkośrednicowych metodą obrotową w określonych odstępach (rys. 1). Pozostawiona między otworami przestrzeń stanowi filary ochronne. Głowica wiercąca ładuje urobek na nawój śrubowy, który transportuje go na zewnątrz, na przenośnik zgrzebłowy lub taśmowy. Metoda charakteryzuje się niskim wykorzystaniem złoża (30-40\%), jednak równocześnie jest tania oraz umożliwia szybkie rozpoczęcie i zakończenie eksploatacji.

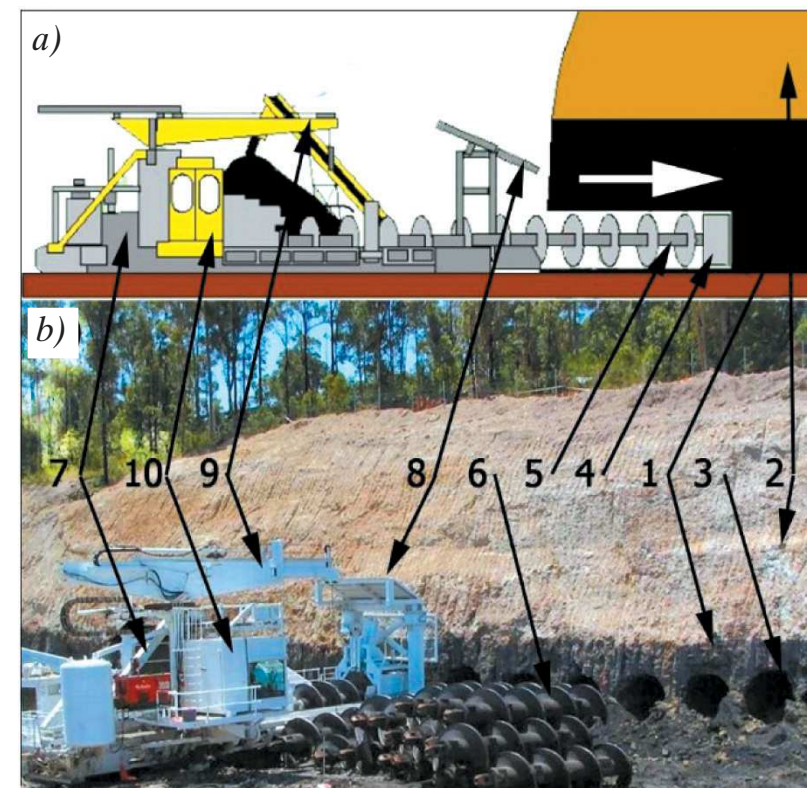

Rys. 1. Metoda auger mining: a) schemat metody;

b) eksploatacja $w$ hrabstwie Nicholas $w$ USA

1 - pokład węgla, 2-nadkład, 3-otwory poeksploatacyjne, 4-głowica wiercaca, 5-żerdź śrubowa, 6-odcinki żerdzi, 7 - napęd, 8 - osłona, 9-juraw, 10 - kabina operatora

Najbardziej zaawansowanym i największym kombajnem stosowanym w tej metodzie jest Auger Miner 1500 (rys. 2) firmy CoalAugering Service PtyLtd (CAS AM 1500). Firma CAS jest australijską firmą oferującą usługi eksploatacji pokładów węgla metodą zwiercania i stosuje technologię firmy BryDet, producenta kombajnu BUA 600 do podziemnej eksploatacji metodą zwiercania.
Zakres średnic głowic wiercacych wynosi od $\phi 1200 \mathrm{~mm}$ do $\phi 1900 \mathrm{~mm}$. Natomiast głębokość wiercenia dochodzi do 203 m dla pojedynczych otworów. Maszyna w miejscu pracy ustawiana jest na odpowiednią wysokość za pomocą kolumn o skoku 2600 mm, co umożliwia oprócz pozycjonowania również wiercenie dwóch otworów poziomych jeden nad drugim. Po wykonaniu otworu i wycofaniu żerdzi maszyna przemieszcza się poprzecznie za pomocą układu kroczącego zbudowanego z dwóch prowadnic wraz z mechanizmem hydraulicznym. Odcinki żerdzi podczas montażu i demontażu (wiercenie, wycofywanie) przenoszone są za pomocą żurawia [9].

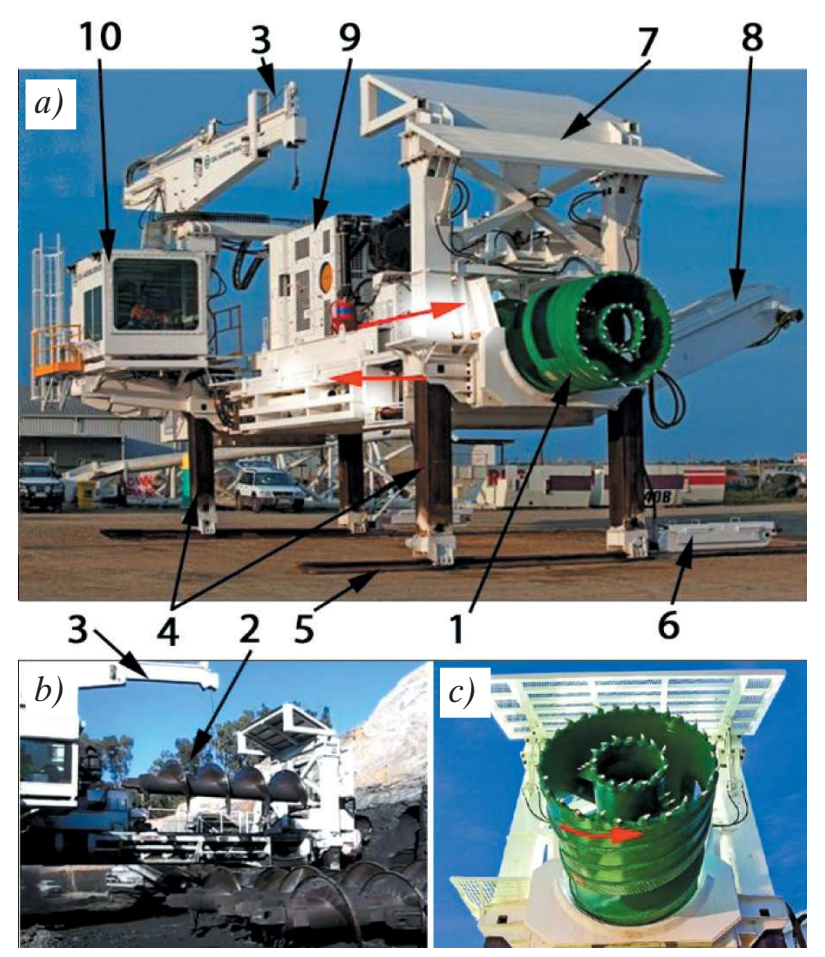

Rys. 2. Kombajn wiercacy typu augerminer: a) maszyna AM1500 firmy CAS; b) montaż żerdzi; c) głowica urabiajaca

1 - głowica wiercaca, 2 - odcinki żerdzi, 3 - zuraw, 4 - kolumny, 5 - belka układu kroczacego, 6-siłowniki układu kroczacego, 7 - ostona, 8 - przenośnik taśmowy, 9 - napęd, 10 - kabina operatora

Kombajny auger miner występują w wielu wersjach różniących się przede wszystkim średnicą wykonywanego otworu oraz liczbą głowic. Średnica otworów mieści się w zakresie od \$400 mm do \$2500 mm i jednocześnie mogą być wykonywane maksymalnie trzy otwory. Przykładem maszyny o najmniejszej średnicy i największej liczbie jednocześnie wykonywanych otworów jest MCK-GS MUL-T (rys. 3) firmy Salem Tool Inc., która może eksploatować pokład trzema głowicami o średnicy $\$ 400$ mm jednocześnie. Długość wierconego otworu dochodzi do $150 \mathrm{~m}$ [10]. 


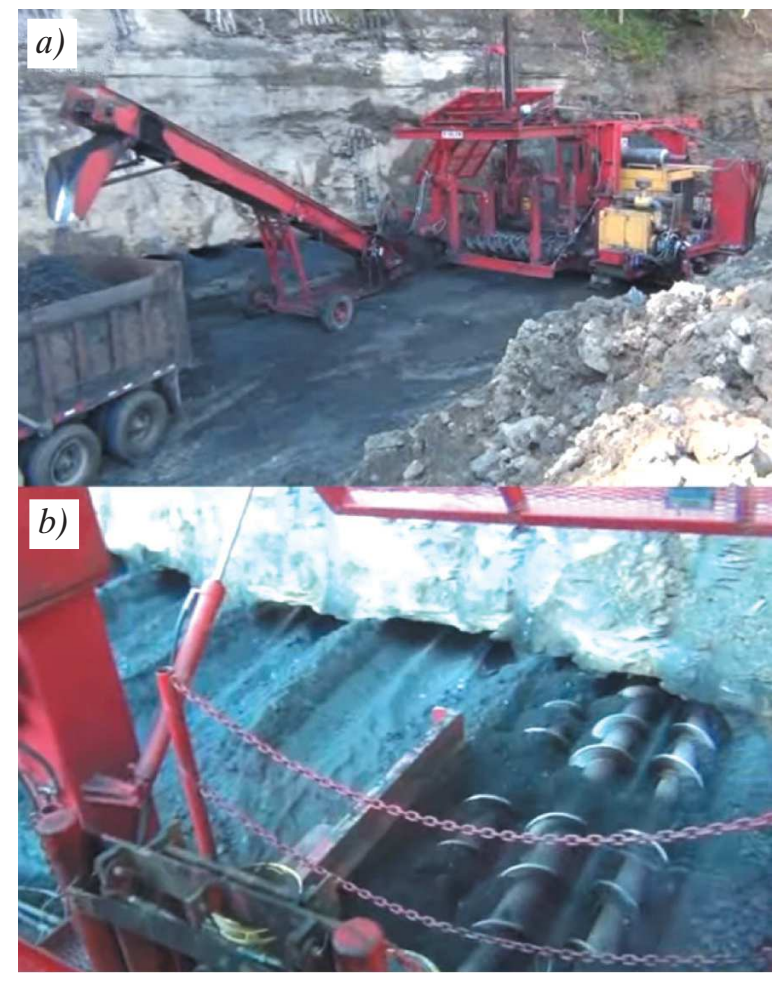

Rys. 3. Kombajn Auger Miner: a) maszyna MCK-GS MUL-T firmy Salem Tool Inc.;

b) wiercenie trzema glowicami

Maszyny służące do eksploatacji metodą zwiercania pozwalają na bardzo szybkie rozpoczęcie eksploatacji i oprócz dostarczenia mediów i utrzymania ruchu wymagają jedynie zapewnienia systemu transportu urobku.

Technologia auger mining w wydaniu podziemnym wykorzystuje również metodę zwiercania, która stosowana jest do eksploatacji pokładów cienkich oraz stromo zalegających. Eksploatacja polega na selektywnym wybieraniu pokładu otworami wielkośrednicowymi. Pomiędzy poszczególnymi otworami pozostawiane są filary chroniące strop. Zarówno technologię, jak i stosowane maszyny na przykładzie górnictwa ukraińskiego i czeskiego można znaleźć w artykułach [11, 12].

Do eksploatacji podziemnej metodą zwiercania służy również kombajn BUA 600 firmy BryDet (rys. 4). Maszyna ta charakteryzuje się ciekawym rozwiązaniem polegającym na zastosowaniu dwóch jednostek: urabiającej oraz wycofującej. Obie jednostki pracują jednocześnie i w trakcie wiercenia oraz wycofywania żerdzie są przekładane z jednego otworu do drugiego, co pozwala na zminimalizowanie zasobnika żerdzi oraz zwiększa efektywność. Zmiana odległości obu jednostek względem siebie decyduje jednocześnie o szerokości filara ochronnego. Kombajn BUA 600 może wykonywać otwory o średnicy od $\phi 1000 \mathrm{~mm}$ do $\phi 1800 \mathrm{~mm}$ na głębokość do $80 \mathrm{~m}$. Moc napędu jednostki wiercącej wynosi $450 \mathrm{~kW}$, natomiast wycofującej-110 kW. Masa całkowita maszyny wynosi $60 \mathrm{Mg}$ i do zabudowania wymaga wyrobiska o szerokości $6 \mathrm{~m}$ oraz wysokości 1,8 m [13]. Kombajn BUA 600 pomimo typowo podziemnego zastosowania został omówiony ze względu na ciekawe i możliwe do zastosowania na powierzchni rozwiązanie techniczne.
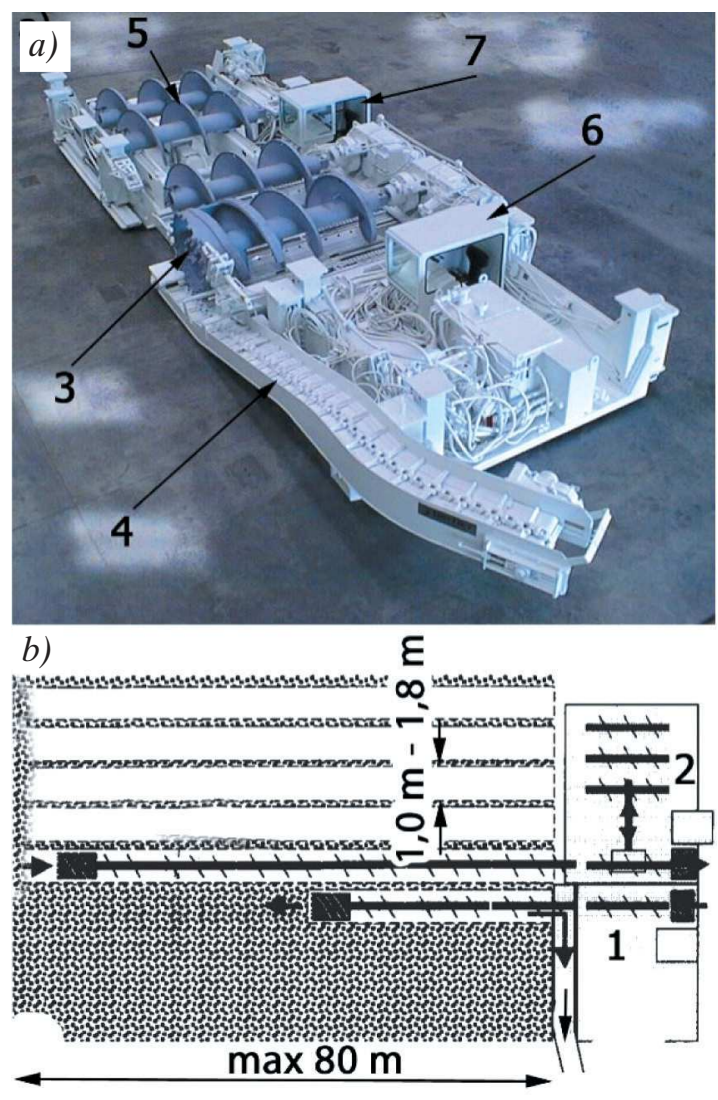

Rys. 4. Kombajn Auger Miner: a) maszyna BUA 600 firmy BryDet; b) technologia pracy

1 - jednostka wiercaca, 2 - jednostka wycofująca, 3 - glowica wiercaca, 4 - przenośnik zgrzebłowy, 5 - odcinki żerdzi, 6-kabina operatora jednostki wiercacej, 7-kabina operatora jednostki wycofujacej

\section{METODA CONTINUOUS HIGHWALL MINING}

Metoda continuous highwall mining początkowo wykorzystywała maszynę urabiającą zbudowaną na bazie kombajnu chodnikowego urabiającego liniowo. W nowszych rozwiązaniach przeznaczonych zwłaszcza do pokładów cienkich stosowana jest odrębna maszyna urabiająca. Metoda polega na wykonywaniu w pokładzie kolejnych chodników rozdzielonych filarami ochronnymi, przez co wykorzystanie złoża waha się w okolicach $60 \%$. Urobek transportowany jest na zewnątrz za pomocą podwójnych przenośników śrubowych. W obu metodach (auger i highwall) eksploatacja odbywa się bez udziału człowieka w przodku, co wyklucza konieczność 
zastosowania klasycznego przewietrzania wyrobisk oraz zabezpieczenia stropów (rys. 5).
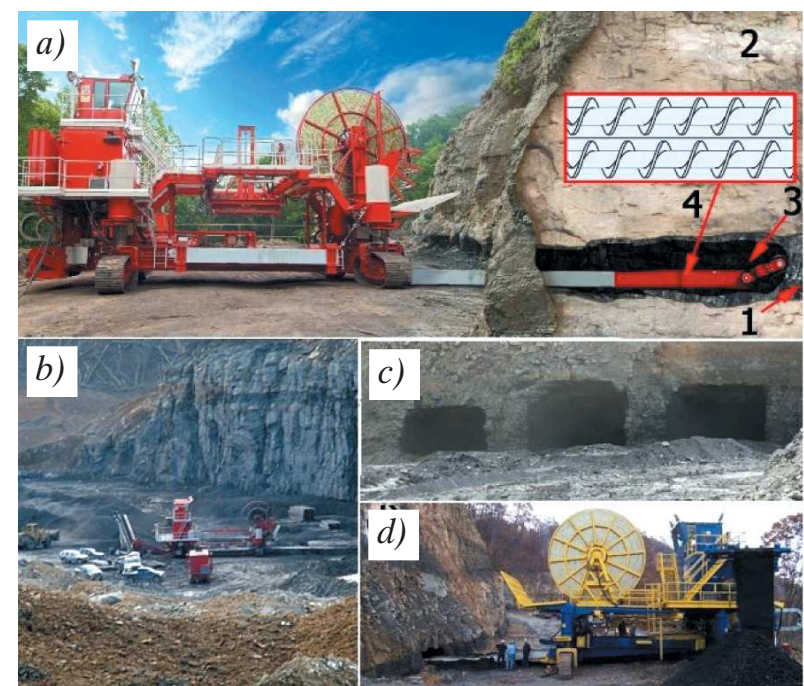

Rys. 5. Metoda highwall mining: a) schemat metody; b) wyposażenie wyrobiska wraz z maszyna Terex SHM; c) wyrobiska po eksploatacji w hrabstwie Mingo w USA; d) kombajn typu AHS (American Highwall Systems) 1 - pokład węgla, 2 - nadkład, 3 - głowica urabiająca,

\section{4 - przenośnik ślimakowy}

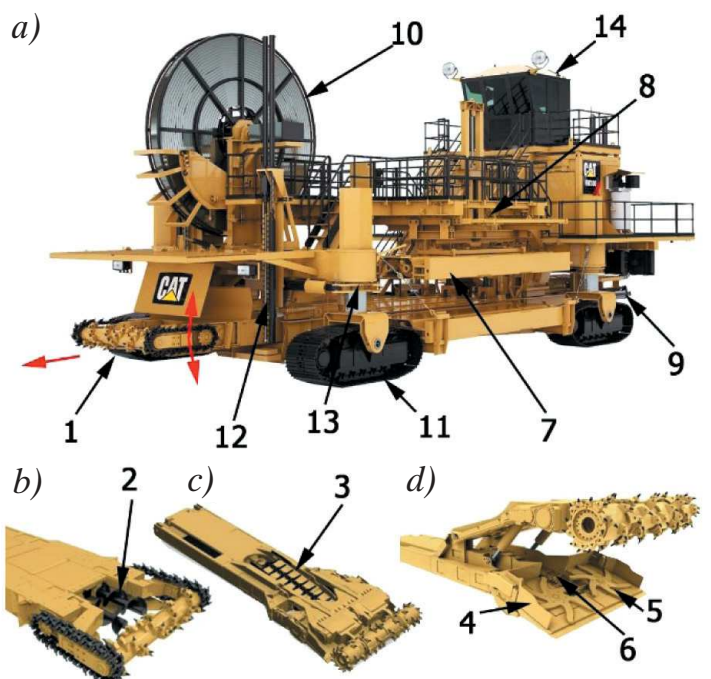

Rys. 6. Kombajn urabiajacy HW300 CAT: a) kombajn; moduly: b) XLPCM; c) LPCM; d) high

1 - głowica urabiająca, 2 - przenośnik ślimakowy, 3 - przenośnik zgrzebłowy, 4 - stót załadowczy, 5 - gwiazdy ładujące, 6 - przenośnik zgrzebłowy, 7 - belka, 8 - suwnica, 9 - siłowniki systemu posuwu, 10 - bęben kablowy, 11 - wózek gąsienicowy, 12 - kotwiarka, 13 - kolumna, 14 - kabina operatora

Maszyną stosowaną w tej technologii jest HW300 firmy CAT, który technicznie jest kombajnem SHM firmy Terex (rys. 6). Kombajn HW300 jest potężną maszyną o mocy całkowitej 1600 kW, ważącą 250 Mg w najlżejszej konfiguracji, która realizuje proces urabiania z zewnątrz na głębokość do $300 \mathrm{~m}$. Maszyna po ustawieniu we właściwej pozycji stabilizowana jest za pomoca dwóch kotwiarek. Eksploatacja odbywa się za pomocą modułu urabiającego wpychanego w caliznę belkami systemu posuwu za pomocą siłowników hydraulicznych o skoku 6,8 m. Belki o długości 6 m stanowią jednocześnie kadłub podwójnego przenośnika ślimakowego i przenoszone są podczas montażu oraz demontażu za pomocą suwnicy. W miarę postępu frontu wszelkie przewody rozwijane są z bębna kablowego [14].

W kombajnie HW300 znajdują się cztery kompatybilne moduły urabiające dobierane do miąższości pokładu:

- XLPCM - moduł ultraniski, średnica organu ф648 mm, wysokość urabiania od $711 \mathrm{~mm}$ do $1549 \mathrm{~mm}$, szerokość urabiania 2946 mm, masa 23,1 Mg;

- LPCM - moduł niski, średnica organu 648 mm, wysokość urabiania od $762 \mathrm{~mm}$ do $1575 \mathrm{~mm}$, szerokość urabiania $2946 \mathrm{~mm}$, masa 23,1 Mg;

- mid - moduł średni, częściowo poza pokładami cienkimi, średnica organu $\phi 965 \mathrm{~mm}$, wysokość urabiania od $1200 \mathrm{~mm}$ do $3060 \mathrm{~mm}$, szerokość urabiania $3505 \mathrm{~mm}$, masa 42,8 Mg. Wyposażony w dodatkowy przenośnik zgrzebłowy;

- high - moduł wysoki, całkowicie poza pokładami cienkimi - średnica organu $\$ 965 \mathrm{~mm}$, wysokość urabiania od $2400 \mathrm{~mm}$ do $4494 \mathrm{~mm}$, szerokość urabiania $3505 \mathrm{~mm}$, masa 48,5 Mg. Wyposażony w stół załadowczy z gwiazdami oraz dodatkowy przenośnik zgrzebłowy.

Kombajn HW300 porusza się na czterech wózkach gąsienicowych mocowanych do kolumn umożliwiających zmianę wysokości położenia modułu urabiającego względem spągu oraz skręt maszyny wraz z możliwością jazdy w poprzek. Długość maszyny wynosi ponad $20 \mathrm{~m}$, szerokość prawie 12 m, a wysokość niemal 9 m [14].

Kombajny do eksploatacji metodą highwall mining występują również w wersji AHS firmy American Highwall Systems. Kombajny AHS dostosowane są do eksploatacji pokładów nachylonych do $30^{\circ}$ oraz pofałdowanych (rys. 6d) [15].

Ciekawą odmianą systemu highwall mining jest system ADDCAR firmy UGM ADDCAR Systems, LLC (rys. 7). System ADDCAR stosowany jest identycznie jak HW300 i przeznaczony jest do eksploatacji pokładów w zakresie miąższości od 0,76 m do 8,54 m, na szerokość około 3,5 m. Jako maszyna urabiająca stosowany jest jeden z kombajnów liniowych firmy CAT lub 
Joy. Można zastosować również kombajn chodnikowy urabiający punktowo. Jednak w każdym przypadku wymagane jest specjalne wykonanie kombajnu, dostosowane do współpracy z systemem ADDCAR.

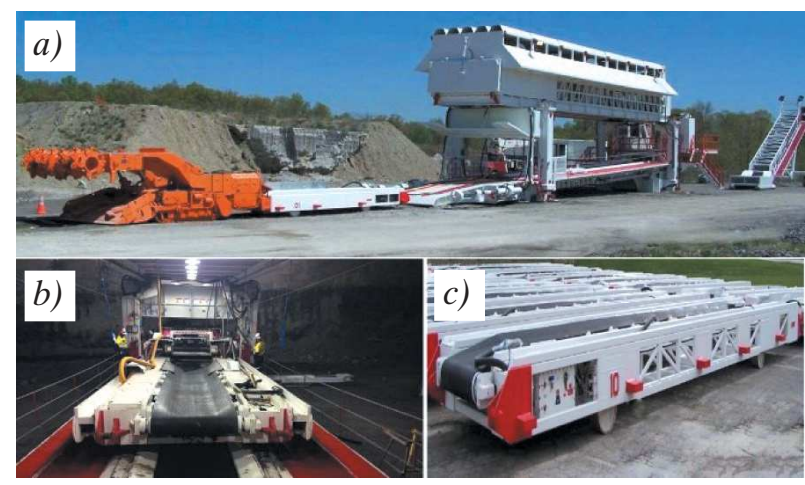

Rys. 7. Maszyny systemu ADDCAR: a) kompleks; b) montaż modułu przenośnika; c) moduły przenośnika

System ten występuje w dwóch odmianach broad oraz narrow bench highwall różniących się maksymalną miąższością urabianego pokładu oraz długością wykonywanego chodnika. Kluczową cechą systemu ADDCAR jest zastosowanie modułów stanowiących niezależne, współpracujące przenośniki taśmowe. Moduły o długości 12,5 m posiadają podwozie kołowe, własny napęd oraz układ sterowania. Dokładane w trakcie eksploatacji moduły łączone są ze sobą mechanicznie oraz elektrycznie. System pozwala na wybieranie węgla chodnikiem o długości do $488 \mathrm{~m}$. Niezaprzeczalną zaletą zastosowania przenośników taśmowych jest znacznie mniejsza degradacja urobku niż podczas transportu przenośnikami ślimakowymi [16].

\section{METODA PUNCH LONGWALL MINING}

Metoda punch longwall mining (rys. 8) polega na eksploatacji systemem ścianowym pokładów, które są udostępnione bezpośrednio z powierzchni przez wykonanie wkopów udostępniających. Wykopy mogą być równoległe bądź prostopadłe do kierunku postępu kompleksu ścianowego, wtedy kierunek eksploatacji odbywa się równolegle do wkopów lub prostopadle od granicy pola eksploatacyjnego w kierunku wykopu. Między kolejnymi polami pozostawiane są filary ochronne. Wyposażenie ściany stanowi zmechanizowany kompleks ścianowy $[8,17]$. Zastosowanie zmechanizowanych systemów ścianowych pozwala na wybieranie pokładów o zróżnicowanej miąższości oraz umożliwia uzyskanie wysokiego, około 90\% wykorzystania złoża.

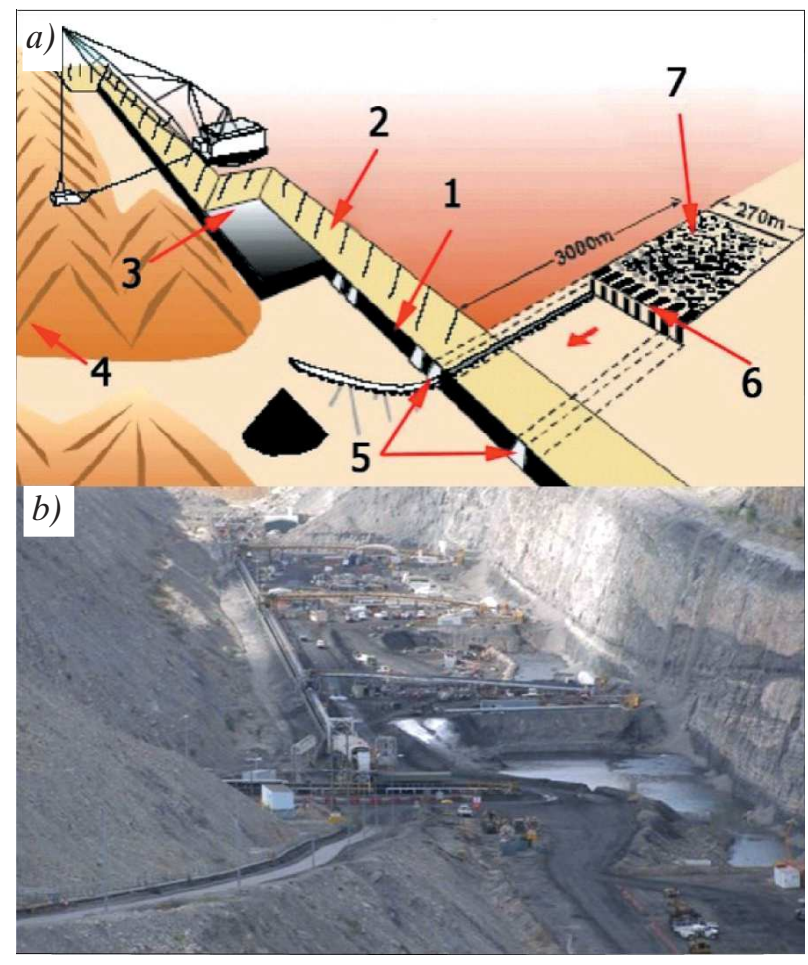

Rys. 8. Punch longwall mining: a) schemat metody;

b) kopalnia Broad meadow w Australii

1 - poktad węla, 2-nadktad, 3-wykop, 4-zwatowisko, 5 - chodniki przyścianowe, 6-kompleks ścianowy,

$$
7 \text {-zroby }
$$

W metodach powierzchniowo-podziemnych stosuje się również przenośniki zgrzebłowe pełzające. Są to rozwiązania zdalnie sterowanych maszyn, które mogą pokonywać różnie usytuowane względem siebie wyrobiska, łącząc maszynę urabiającą z kolejnymi środkami odstawy. Rozwiązanie takie umożliwia zastosowanie różnych zintegrowanych z przenośnikami maszyn urabiających.

\section{PODSUMOWANIE}

Eksploatacja cienkich i silnie nachylonych pokładów w zależności od wielu czynników odbywa się przy zastosowaniu różnych metod i maszyn. Na przestrzeni lat stosowano bardzo zróżnicowane maszyny urabiające, obecnie pozostały nieliczne, sprawdzone rozwiązania. Jednak uwarunkowania występujące jedynie lokalnie przyczyniły się do rozwoju metod eksploatacji i stosowanych w nich maszynach, używanych na niewielką skalę w różnych zakątkach świata. Przedstawiony w artykule oraz w literaturze [5-8] przegląd metod, systemów oraz maszyn urabiających wskazuje na ich duże zróżnicowanie. Zaprezentowane w artykule maszyny 
rozwijane są i stosowane od wielu lat. Mimo dużej różnorodności metod sposób urabiania sprowadza się do frezowania lub wiercenia. W zależności od zastosowanej metody oraz ewentualnej konieczności ochrony powierzchni nad wyrobiskami wykorzystanie złoża waha się od 30\% do $40 \%$ dla metody auger mining, $60 \%$ dla metody highwall mining, około $90 \%$ dla systemów ścianowych.

W artykule skupiono się na niespotykanych w Polsce maszynach, przystosowanych do urabiania cienkich pokładów węgla kamiennego. To, że nie są one stosowane w kraju, spowodowane jest brakiem korzystnych warunków górniczo-geologicznych oraz brakiem możliwych do eksploatacji pokładów płytko zalegających lub eksponowanych.

Wszystkie z przedstawionych metod stosowane są również do eksploatacji pokładów średnich i grubych. Maszyna urabiająca charakteryzuje się wtedy większą wysokością urabiania. Wyjątek stanowi metoda zwiercania, gdzie maksymalna średnica głowicy wynosi $\$ 2500$ mm, a otwory wykonuje się w dwóch rzędach w pionie.

\section{Podziękowania}

Prace finansowane z grantu dziekańskiego na Wydziale Inżynierii Mechanicznej i Robotyki AGH w ramach umowy numer 15.11.130.838.

\section{Literatura}

[1] Antoniak J., Opolski T.: Maszyny górnicze. Czesść 2: Maszyny do eksploatacji podziemnej, Wydawnictwo „Śląsk”, Katowice 1979.

[2] Opolski T.: Elementy urabiajace nowoczesnych maszyn roboczych, Wydawnictwo „Śląsk”, Katowice 1966.

[3] Bołoz Ł.: Ocena obciażenia jednoorganowego kombajnu ścianowego na podstawie badań analitycznych, AGH w Krakowie, Kraków 2012 [praca doktorska].

[4] Piechota S.: Podstawowe zasady i technologie wybierania kopalin statych, Biblioteka Szkoły Eksploatacji Podziemnej, Kraków 2003.
[5] Kotwica K., Mendyka P., Bołoz Ł. et al.: Wybrane problemy urabiania, transportu i przeróbki skat trudnorabialnych. Czesśc I, pod red. Krauze K., Wydawnictwa AGH, Kraków 2016.

[6] Czaplicki J.: Mechanizacja w górnictwie okruchowym i skalnym. Kopalnie odkrywkowe złóż pokładowych $i$ rud metalicznych, Wydawnictwo Politechniki Ślaskiej, Gliwice 2013.

[7] Bołoz Ł.: Maszyny urabiajace $w$ wybranych metodach eksploatacji cienkich pokładów węgla kamiennego, „Systemy Wspomagania w Inżynierii Produkcji, Górnictwo - Perspektywy i Zagrożenia: Węgiel, Tania Czysta Energia i Miejsca Pracy" 2018, 7, 1: 131-142.

[8] Bołoz Ł.: Maszyny urabiające $w$ ścianowych systemach eksploatacji cienkich pokładów węgla kamiennego, „Systemy Wspomagania w Inżynierii Produkcji, Górnictwo - Perspektywy i Zagrożenia: Węgiel, Tania Czysta Energia i Miejsca Pracy" 2018, 7, 1: 143-154.

[9] Coal Augering Services Pty Ltd, www.coalaugering.com [20.03.2018].

[10] Salem Tool Inc., www.salemtoolinc.com [20.03.2018].

[11] Rak Z., Skrzypkowski K., Stasica J.: Eksploatacja pokładów cienkich metodą zwiercania, „Przegląd Górniczy” 2014, 2: 18-24.

[12] Stonis M., Hudecek V.: Mining of Coal Pillars Using the Drilling Method, „Acta Montanistica Slovaca” 2009, 3: 241-249.

[13] BryDet, www.brydet.com [29.06.2018].

[14] Caterpillar Inc. (CAT), www.cat.com [29.06.2018].

[15] American Highwall Systems, American Highwall Mining Llc, http://americanhighwallsystems.com [29.06.2018].

[16] UGMADDCARSystems,LLC.,https://addcarsystems.com [29.06.2018].

[17] Bołoz Ł.: Longwall shearers for exploiting thin coal seams as well as thin and highly inclined coal seams, ,Mining - Informatics, Automation and Electrical Engineering" 2018, 2: 59-65.

drinz. $ヒ U K A S Z B O E O Z$

Katedra Maszyn Górniczych, Przeróbczych

$i$ Transportowych

Wydziat Inżynierii Mechanicznej i Robotyki AGH Akademia Górniczo-Hutnicza im. Stanisława Staszica w Krakowie al. Mickiewicza 30, 30-059 Kraków boloz@agh.edu.pl 